\begin{tabular}{|c|c|}
\hline 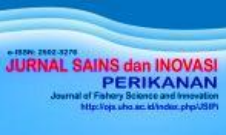 & $\begin{array}{c}\text { JURNAL SAINS dan INOVASI PERIKANAN } \\
\text { Journal of Fishery Science and Innovation } \\
\text { e-ISSN: } 2502-3276\end{array}$ \\
\hline जबाल & $\begin{array}{c}\text { Vol. 1, No.2, 35-41, Juli } 2017 \\
\text { http://ojs.uho.ac.id/index.php/JSIPi }\end{array}$ \\
\hline
\end{tabular}

\title{
Suksesi Tingkat Penempelan Biofouling pada Rumput Laut (Eucheuma denticulatum) yang Dipelihara dengan Metode Rakit Jaring Apung dan Long Line di Perairan Tanjung Tiram, Kabupaten Konawe Selatan
}

\section{Stickness Succession Level of Biofouling on seaweeds (Eucheuma denticulatum) which protected using Floating Cages and Long Line on the Water of Tanjung Tiram, South Konawe Regency}

\author{
Isman Septian Ismail $^{\left.12)^{*}\right)}$, Ma'ruf Kasim ${ }^{3)}$, Rahmad Sofyan Patadjai ${ }^{3)}$ \\ ${ }^{1)}$ Mahasiswa Program Studi Ilmu Perikanan Program Pascasarjana Univ. Halu Oleo, Kendari, Indonesia \\ ${ }^{2)}$ Dinas Kelautan dan Perikanan Kota Kendari, Indonesia \\ ${ }^{3)}$ Fakultas Perikanan dan Ilmu Kelautan Universitas Halu Oleo, Kendari, Indonesia \\ Corresponding authors ${ }^{*}$ :Isman_septian@yahoo.com, ${ }^{3)}$ marufkasim@ hotmail.com, ${ }^{3)}$ yb8khr_unhalu@yahoo.co.id
}

\begin{abstract}
One of the problem faced by seaweed cultivation is stickness of biofouling on thallus and substrate that become a competitor of seaweed growth. This study was aimed at finding out types of biofouling that's sticks on substrate and seaweed and its influence to seaweed growth. This research was conducted from December 2016 to February 2017 on the water of Tanjung Tiram, South Konawe Regency. The research process was carried out by placing 100 thallus of seaweed were cultivated using Floating Cages and Long Line then observed in term of biofouling stickness succession on the thallus and substrate for 7 weeks. Biofouling was observed on substrate using $10 \times 10 \mathrm{~cm}^{2}$ transects placed randomly in five points, while on thallus observed using $1 \times 1 \mathrm{~cm}^{2}$ transects with using loop. The types of biofouling were 21 species, among others, Hypnea asperi, Caetomorpha crassa, Cladophora sp., acanthopora spicifera, Ulva fasciata, Udotea flabellum, Laurencia nidifica, polysiphonia sp., Gracilaria Salicornia, Elachista flaccida, Padina Australis, Dictyota dichotoma, agelas clathrodes, Diddemnum molle, Patella vulgata, Nucella lapillus, Turbo brunneus, Mytilopsis sallei, Brachidontes maritimus, Hemigrapsus crenulatus and unidentified molusca.
\end{abstract}

Keywords : Succession, biofouling, floating cage, long line

\begin{abstract}
ABSTRAK
Salah satu permasalahan dalam kegiatan budidaya rumput laut adalah penempelan biofouling pada thallus maupun substrat yang menjadi kompetitor sehingga menyebabkan tergganggunya pertumbuhan rumput laut. Tujuan dari penelitian ini adalah untuk mengetahui jenis-jenis biofouling yang menempel pada substrat dan rumput laut serta pengaruhnya terhadap pertumbuhan rumput laut. Penelitian dilakukan pada bulan Desember 2016 - Februari 2017 di perairan Tanjung Tiram, Kabupaten Konawe Selatan. Penelitian dilakukan dengan menggunakan 100 thallus rumput laut yang dibudidayakan pada rakit jaring apung dan Long Line selama 7 minggu Pengamatan Biofouling pada substrat dilakukan dengan menggunakan transek 10 x $10 \mathrm{~cm}^{2}$ yang diletakkan secara acak pada lima (5) titik, sedangkan pada thallus dilakukan dengan menggunakan transek $1 \mathrm{x} 1$ $\mathrm{cm}^{2}$ dengan bantuan loop. Adapun jenis Biofouling yang ditemukan sebanyak 21 spesies diantaranya Hypnea asperi, Caetomorpha crassa, Cladophora sp., acanthopora spicifera, Ulva fasciata, Udotea flabellum, Laurencia nidifica, polysiphonia sp., Gracilaria Salicornia, Elachista flaccida, Padina Australis, Dictyota dichotoma, agelas clathrodes, Diddemnum molle, Patella vulgata, Nucella lapillus, Turbo brunneus, Mytilopsis sallei, Brachidontes maritimus, Hemigrapsus crenulatus dan unidentified moluska.
\end{abstract}

Kata Kunci: Suksesi, biofouling, rakit jaring apung, long line

DOI: http://dx.doi.org/10.33772/jspi.v1n2. 
36 Isman Septian Ismail et al

JURNAL SAINS dan INOVASI PERIKANAN / Journal of Fishery Science and Innovation

Vol. 1, No. 2, 35-41, Juli 2017

\section{PENDAHULUAN}

Rumput laut merupakan alga laut yang hidup pada perairan yang dangkal (mendominasi lingkungan bentik). Rumput laut menjadi sumber makanan utama dan juga sebagai habitat untuk berbagai organisme laut (Ahmed and Taparhudee, 2005; Athithan, 2014). Hingga saat ini, rumput laut telah dibudidayakan dan telah berkembang di banyak Negara seperti Jepang, Cina, Korea, Taiwan, Filipina, Malaysia, Indonesia dan Thailand (Ask and Azanza, 2002; Onho, 2004; Kavale et al, 2016).

Pada umumnya budidaya rumput laut menggunakan metode long line (Ask and Azanza, 2002). Metode long line merupakan suatu metode budidaya yang tidak berbasis substrat dasar perairan sehingga memungkinkan rumput laut terbebas dari hama bulu babi akan tetapi sangat rentan terhadap penempelan dari biofouling dan pemangsaan organisme herbivora (Soegiarto, 2005). Aktifitas pemangsaan oleh organisme herbivora dapat menurunkan total produksi rumput laut hingga mencapai 60\% (Kasim and Asnani, 2012).

Saat ini telah dikembangkan metode budidaya yang dapat memproteksi rumput laut dari organisme herbivora yaitu metode rakit jaring apung. Metode rakit jaring apung merupakan metode budidaya dengan cara menyimpan rumput laut di dalamnya tanpa mengikatnya dengan demikian dapat terlindung dari organisme herbivora (Kasim, 2016). Metode rakit jaring apung dapat melindungi rumput laut dari pemangsaan organisme herbivora akan tetapi dapat menyebabkan penempelan dari biofouling karena adanya jaring yang dapat menjadi media penempelan biofouling.

Biofouling merupakan hasil dari penempelan dan pertumbuhan berbagai kumpulan tumbuhan dan hewan (Evans \& Hoaglands, 1986; Railkin, 2004). Kehadiran Biofouling dapat memberikan efek negatif bagi pertumbuhan rumput laut maupun substrat metode budidaya. Biofouling dapat menjadi kompetitor bagi organisme dalam pemenuhan zat hara (Sievers et al, 2013) dan menghalangi rumput laut dalam menyerap sinar matahari dan dapat mempengaruhi daya tahan thallus rumput laut terhadap penyakit sehingga pertumbuhan thallus rumput laut menjadi kerdil dan kurus dan laju pertumbuhan akan rendah (Murniati., $d k k, 2015$ ), sedangkan penempelan Biofouling pada substrat dapat menyebabkan penambahan bobot pada konstruksi budidaya serta menghambat sirkulasi air dalam rakit (Tan et al., 2002; Braithwaite \& McEvoy, 2005; Lacoste et al, 2014).

Kegiatan budidaya rumput laut merupakan kegiatan yang menjadi mata pencaharian untuk masyarakat yang hidup di wilayah pesisir khususnya di perairan Tanjung Tiram. Dalam pelaksanaan budidaya rumput laut sering ditemui adanya biofouling yang sering kali menjadi penghambat pertumbuhan dari rumput laut yang dibudidaya sehingga dapat mempengaruhi daya tahan rumput laut tersebut terhadap penyakit. Penelitian tentang metode rakit apung untuk budidaya masih tergolong baru untuk penerapannya bila dibandingkan dengan metode rawai (long line) yang selama ini umumnya digunakan oleh pembudidaya. Penelitian ini sangat perlu dilakukan untuk menghadapi beberapa permasalahan yang dihadapi oleh petani rumput laut terhadap penempelan biofouling dalam kegiatan budidaya rumput laut.

Tujuan penelitian ini adalah untuk mengetahui mengetahui jenis-jenis biofouling yang menempel pada rumput laut serta pengaruhnya terhadap pertumbuhan rumput laut.

\section{METODE PENELITIAN}

Penelitian ini dilaksanakan pada areal budidaya rumput laut Perairan Tanjung Tiram, Kabupaten Konawe Selatan yang dilaksanakan pada bulan Desember 2016- Februari 2017. Rakit jaring Apung terletak pada posisi $04^{0} 01^{\prime} 57.0$ " LS dan $122^{\circ} 40^{\prime} 30.5^{\prime \prime}$ BT yang terletak diatas habitat karang dengan substrat pasir berbatu. Long line terletak pada posisi $04^{0} 01$ '57.1" LS dan $122^{0} 46^{\prime} 26.5^{\prime \prime}$ BT dengan substrat pasir berbatu yang didominasi karang mati.

\section{Penelitian Lapangan}

Pengamatan suksesi penempelan dilakukan dengan menggunakan rakit jaring apung dan long line. Berat awal masing-masing rumput laut adalah sebesar $20 \mathrm{~g}$ per rumpun dimana masing-masing petak rakit jaring apung diisi sebanyak masingmasing 25 rumpun. Pada long line jumlah rumput laut yang diikat setiap bentangan sebanyak 25 rumpun dengan total 4 bentangan. 
Pengamatan biofouling dilakukan selama 7 minggu dalam rentang waktu 1 minggu dengan pengambilan mulai hari ke-0 penanaman rumput laut hingga hari ke-7 pengambilan pertama. Untuk pengamatan biofouling pada thallus rumput laut dilakukan dengan cara mengambil masing-masing 3 rumpun pada setiap petak rakit jaring apung dan long line kemudian diamati menggunakan transek $1 \times 1 \mathrm{~cm}^{2}$ yang diamati dengan bantuan loop.

Pengamatan biofouling pada substrat dilakukan dengan cara menempatkan transek $10 \times 10 \mathrm{~cm}^{2}$ yang diletakkan secara acak pada lima (5) titik. Biofouling yang ditemui pada substrat dan thallus diidentifikasi jenis dan dihitung jumlah individu dari setiap spesiesnya. Biofouling jenis $C$. crassa yang tidak bisa dihitung, ditimbang dengan menggunakan timbangan dengan ketelitian $0,1 \mathrm{~g}$.
Untuk mengetahui pengaruh kehadiran biofouling, setiap minggu penelitian dilakukan pula penimbangan thallus rumput laut baik yang dipelihara dengan rakit jaring apung maupun long line.

Identifikasi Biofouling dilakukan mengacu pada pedoman Trono (1986), Dawes (1981), Barret \& Yonge (1985) dan identifikasi online yaitu www.algabase.com.

Biofouling yang ditemukan dihitung jumlahnya dan dianalisis kepadatannya menggunakan persamaan :

$$
\mathrm{Di}=\frac{n i}{A}
$$

Dimana: Di $=$ Kepadatan jenis biofouling $\left(\mathrm{ind} / \mathrm{m}^{3}\right)$; $\mathrm{ni}=$ Jumlah total individu spesies ke-i; $\mathrm{A}=$ Luas area $\left(\mathrm{m}^{3}\right)$.

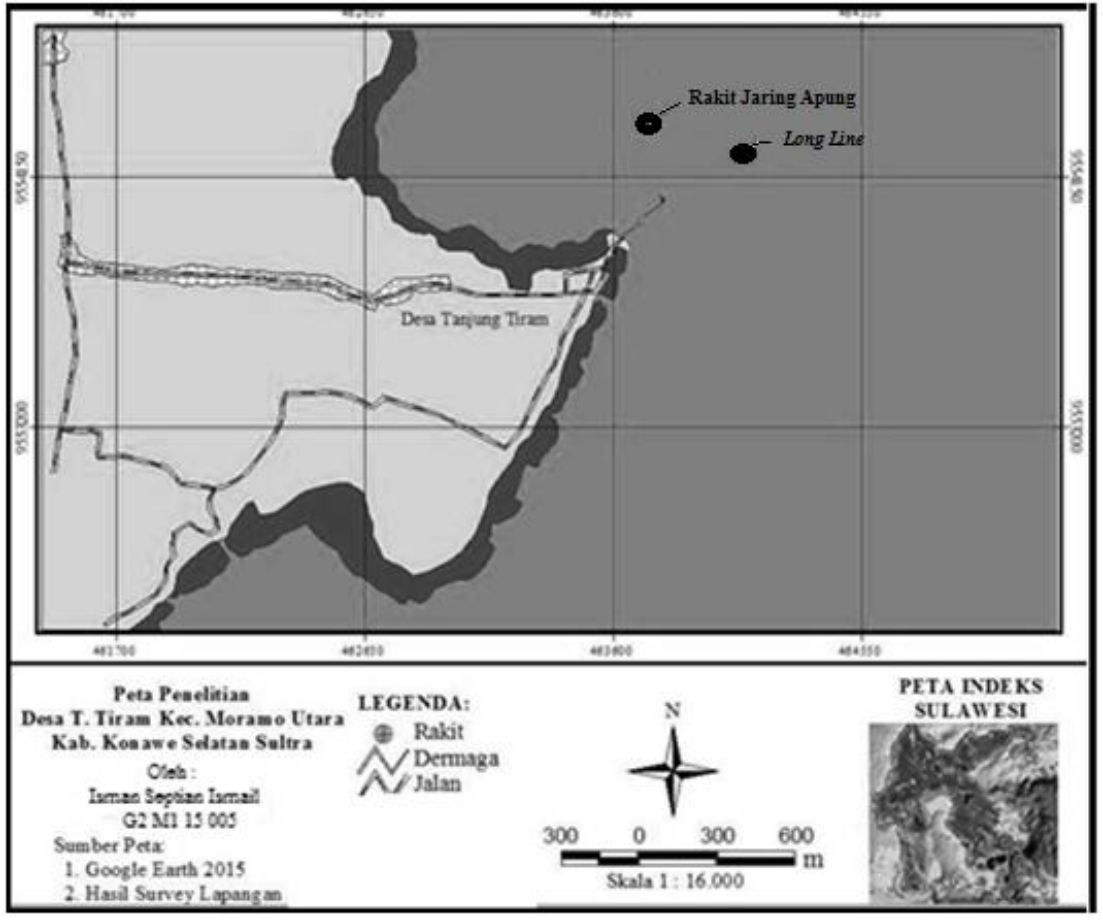

(a)

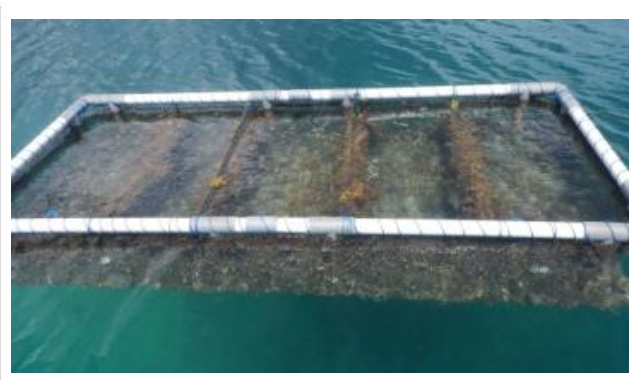

(b)

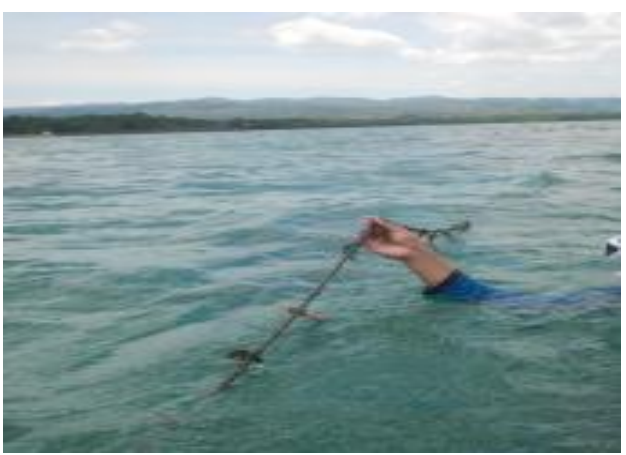

(c)

Gambar 1. (a) Peta Lokasi Penelitian; (b). Rakit Jaring Apung; (c). Long line 
38 Isman Septian Ismail et al

JURNAL SAINS dan INOVASI PERIKANAN / Journal of Fishery Science and Innovation

Vol. 1, No. 2, 35-41, Juli 2017

\section{Parameter Kualitas Perairan}

Pengamatan kualitas perairan dilakukan selama 7 kali pengamatan dalam 7 minggu dengan rentang waktu 1 minggu. parameter kualitas perairan yang diukur adalah suhu, salinitas, kecerahan, kecepatan arus, nitrat dan fosfat.

\section{HASIL DAN PEMBAHASAN}

\section{Hasil}

Penempelan biofouling pada rakit jaring apung minggu ke-1 ditandai dengan penempelan Cladophora sp., L. nidifica, dan P. australis pada substrat. Pada minggu ke-2 diikuti dengan kemunculan spesies makroepifit $H$. asperi, $C$. crassa, A. spicifera, polysiphonia sp., E. flaccida sedangkan spesies makrofauna ditandai dengan kehadiran $P$. vulgata, $T$. brunneus dan $H$. Cranulatus. Memasuki minggu ke-3, pada thallus rumput laut mulai ditemukan penempelan $C$. crassa dan Cladophora sp. sedangkan pada substrat spesies H. cranulatus tidak ditemukan. Pada minggu ke-4, pada thallus ditemukan spesies $U$. flabellum sedangkan pada substrat ditemukan spesies $U$. flabellum, G. salicornia, $D$. dichotoma dan makrofauna yaitu M. sallei, B. maritimus dan $H$. Cranulatus. Minggu ke-5, spesies $U$. flabellum mulai menghilang pada thallus dan substrat dimana pada thallus hanya ditemukan spesies $C$. crassa dan pada substrat ditemukan spesies $N$. lapillus. Pada minggu ke-6, spesies $C$. crassa mulai menghilang pada thallus maupun substrat dan digantikan kehadirannya oleh spesies $U$. fasciata. Pada minggu ke-7, di substrat ditemukan spesies makrofauna Unidentified moluska

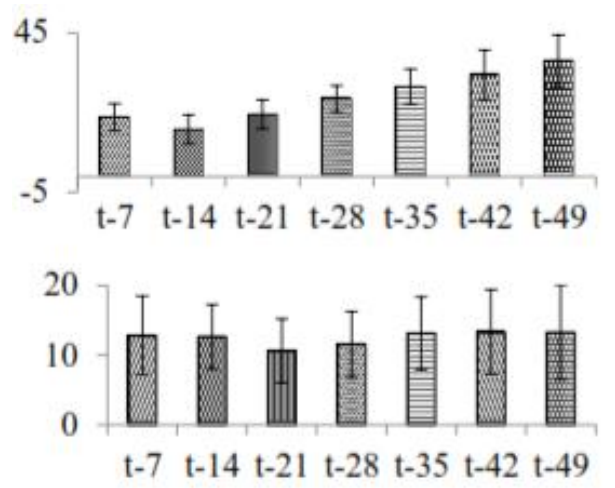

Gambar 2. Bobot basah rumput laut yang pelihara pada: (a) rakit jaring apung; (b) Long Line

Tabel 1. Kepadatan Biofouling pada rakit jaring apung

\begin{tabular}{|c|c|c|c|c|c|c|c|c|c|c|c|c|c|c|c|c|}
\hline \multirow{3}{*}{ No } & \multirow{3}{*}{ Kelas } & \multirow{3}{*}{ Spesies } & \multicolumn{7}{|c|}{ Thallus } & \multicolumn{7}{|c|}{ Substrat } \\
\hline & & & \multicolumn{14}{|c|}{ Minggu Ke - } \\
\hline & & & 1 & 2 & 3 & 4 & 5 & 6 & 7 & 1 & 2 & 3 & 4 & 5 & 6 & 7 \\
\hline I & Chlorophyta & H. asperi & - & - & - & - & - & - & - & - & 700 & 1200 & 1900 & 2100 & 2300 & 2600 \\
\hline 2 & & C.crassa & - & - & 500 & & 1900 & - & - & - & 2700 & 6000 & 13300 & 15700 & - & - \\
\hline 3 & & Cladophora sp. & - & - & 200 & 400 & - & - & - & 1100 & 500 & 700 & 800 & 1400 & 2600 & 2900 \\
\hline 4 & & A.spicifera & - & - & - & - & - & - & - & - & 3100 & 1900 & 1600 & 1900 & 2100 & 2600 \\
\hline 5 & & $U$. fasciata & - & - & - & - & - & 300 & 600 & - & - & - & - & - & 400 & 900 \\
\hline 6 & & U. flabellum & - & - & - & 200 & - & - & - & - & - & - & 200 & - & - & - \\
\hline 7 & Rhodophyta & L. nidifica & - & - & - & - & - & - & - & 700 & 2300 & 3100 & 3500 & 3700 & 4100 & 4700 \\
\hline 8 & & Polysiphonia sp. & - & - & - & - & - & - & - & - & 1900 & 3600 & 2700 & 3100 & 4500 & 4900 \\
\hline 9 & & G. Salicornia & - & - & - & - & - & - & - & - & - & - & 300 & 600 & 900 & 1400 \\
\hline 10 & Phacophyta & E. flaccida & - & - & - & - & - & - & - & - & 1300 & 1900 & 2100 & 2900 & 3400 & 4100 \\
\hline 11 & & $P$. Australis & - & - & - & - & - & - & - & 1800 & 3400 & 4100 & 4700 & 4100 & 3500 & 2200 \\
\hline 12 & & D. dichotoma & - & - & - & - & - & - & - & - & - & - & 700 & 1300 & 1600 & 2100 \\
\hline 13 & Sponge & A. clathrodes & - & - & - & - & - & - & - & - & - & - & - & - & - & - \\
\hline 14 & Tunicata & D. malle & - & - & - & - & - & - & - & - & - & - & - & - & - & - \\
\hline 15 & Gastropoda & P. vulgata & - & - & - & - & - & - & - & - & 1200 & 3200 & 3900 & 4600 & 6100 & 6300 \\
\hline 16 & & N. lapilus & - & - & - & - & - & - & - & - & - & - & - & 200 & 600 & 1100 \\
\hline 17 & & T.brunneus & - & - & - & - & - & - & - & - & 300 & 900 & 1400 & 1500 & 1300 & 1800 \\
\hline 18 & Bivalvia & M. sallei & - & - & - & - & - & - & - & - & - & - & 200 & 600 & 1100 & 1500 \\
\hline 19 & & B. maritimus & - & - & - & - & - & - & - & - & - & - & 100 & 300 & 500 & 900 \\
\hline 20 & Crustacea & H. cremulatus & - & - & - & - & - & - & - & - & 200 & - & 100 & 200 & 300 & 200 \\
\hline 21 & Moluska & $\begin{array}{l}\text { Unidentified } \\
\text { spesies }\end{array}$ & - & - & - & - & - & - & - & - & - & - & - & - & - & 200 \\
\hline \multicolumn{3}{|c|}{ Total (Ind $\left./ \mathrm{m}^{3}\right)$} & 0 & 0 & 700 & 1700 & 1900 & 300 & 600 & 3600 & 17600 & 26600 & & 44200 & 35300 & 40400 \\
\hline & Total Keselur & Ihan $\left(\right.$ Ind/m $\left.\mathrm{m}^{3}\right)$ & & & & 520 & & & & \multicolumn{7}{|c|}{205200} \\
\hline
\end{tabular}


Vol. 1, No. 2, 35-41, Juli 2017

Tabel 2. Kepadatan Biofouling pada Long line

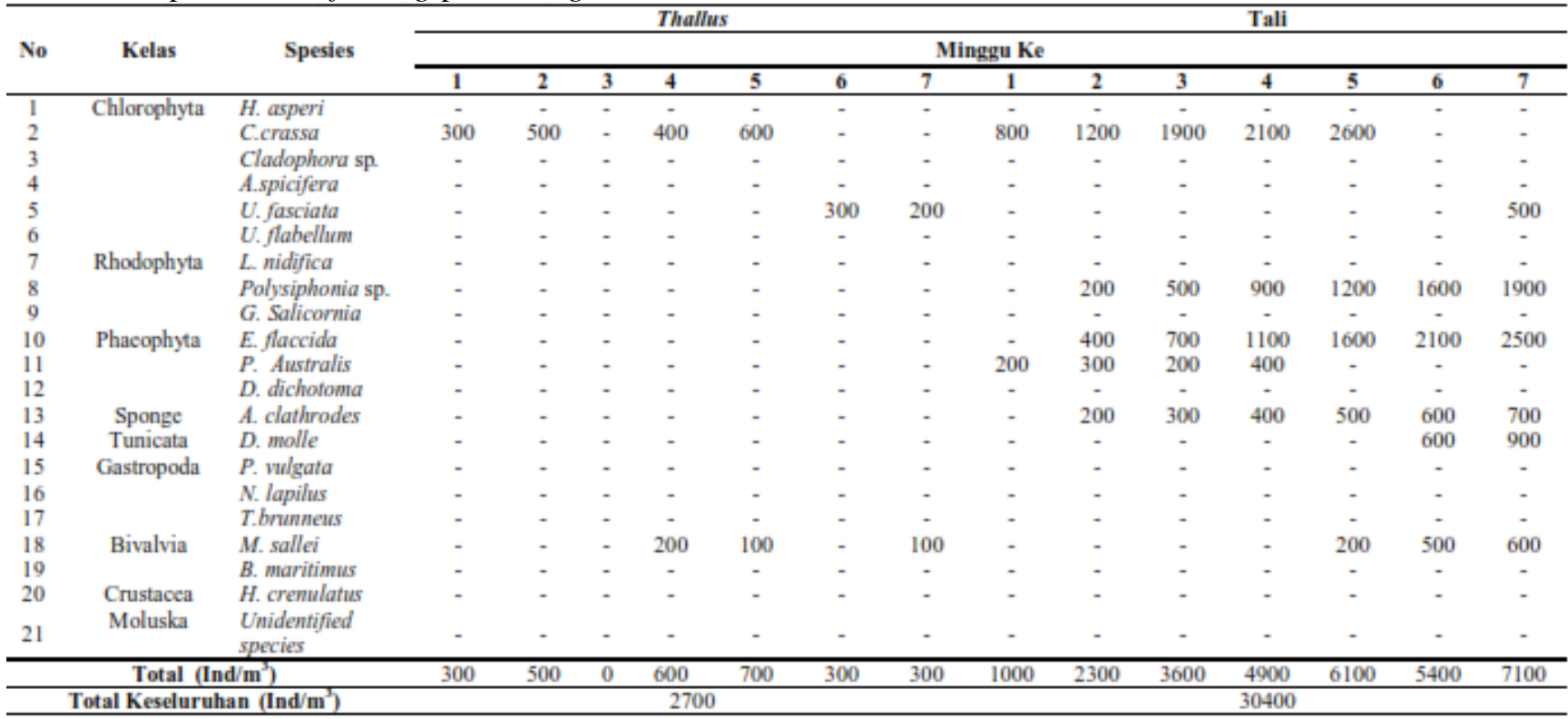

Tabel 3. Parameter Kualitas Perairan selama periode penelitian

\begin{tabular}{|c|c|c|c|c|c|c|c|c|c|c|c|c|c|c|c|}
\hline \multirow{3}{*}{ Parameter } & \multicolumn{8}{|c|}{ Rakit Jaring Apung } & \multicolumn{6}{|c|}{ Long Line } & \multirow{3}{*}{$\begin{array}{c}\text { Kelayakan untuk } \\
\text { Pertumbuhan } \\
\text { Biofouling Menurut } \\
\text { Pustaka }\end{array}$} \\
\hline & \multicolumn{14}{|c|}{ Minggu $\mathrm{Ke}$ - } & \\
\hline & 1 & 2 & 3 & 4 & 5 & 6 & 7 & 1 & 2 & 3 & 4 & 5 & 6 & 7 & \\
\hline \multicolumn{16}{|l|}{ Fisika } \\
\hline Suhu $\left({ }^{\circ} \mathrm{C}\right)$ & 34 & 32 & 33 & 33 & 32 & 30 & 34 & 34 & 32 & 33 & 33 & 33 & 30 & 34 & $\begin{array}{l}20 \text { - } 35 \text { (Railkin, } \\
2004)\end{array}$ \\
\hline $\begin{array}{l}\text { Kecepatan } \\
\text { arus }(\mathrm{m} / \mathrm{s})\end{array}$ & 16.24 & 14.18 & 19.57 & 16.21 & 18.91 & 14.55 & 13.42 & 20.36 & 21.11 & 21.68 & 23.79 & 22.61 & 16.78 & 19.71 & $\begin{array}{l}0,10-0,50 \text { (Dubost } \\
\text { ef } a l, 1996) \text {; (Railkin } \\
2004 \text { ) }\end{array}$ \\
\hline $\begin{array}{l}\text { Kecerahan } \\
\text { perairan (m) }\end{array}$ & 5.075 & 4.9 & 5.9 & 5.045 & 5.75 & 4.95 & 4.65 & 6.25 & 6.4 & 6.75 & 6.85 & 6.8 & 5.25 & 6.05 & $\begin{array}{l}5-10 \text { (Hudson ef al, } \\
\text { 2000); (Railkin, } \\
\text { 2004) }\end{array}$ \\
\hline \multicolumn{16}{|l|}{$\overline{\text { Kimia }}$} \\
\hline Salinitas (ppt) & 33 & 33 & 32 & 34 & 33 & 31 & 35 & 33 & 33 & 32 & 34 & 33 & 31 & 34 & $\begin{array}{l}32-35 \\
\text { (Dawes, 1981); } \\
\text { (Railkin, 2004) }\end{array}$ \\
\hline Nitrat (mg/) & 0.011 & 0.014 & 0.011 & 0.017 & 0.013 & 0.011 & 0.012 & 0.011 & 0.011 & 0.012 & 0.014 & 0.013 & 0.011 & 0.014 & $\begin{array}{l}0,001-0,012 \\
\text { (Railkin, 2004) }\end{array}$ \\
\hline Fosfat (mgl) & 0.006 & 0.007 & 0.004 & 0.004 & 0.009 & 0.009 & 0.001 & 0.004 & 0.003 & 0.003 & 0.005 & 0.005 & 0.008 & 0.001 & $\begin{array}{l}0,0012-0,0055 \\
\text { (Railkin, 2004) }\end{array}$ \\
\hline
\end{tabular}

Penempelan biofouling pada long line minggu ke-1 ditandai dengan penempelan spesies $C$. crassa dan $P$. australis pada substrat sedangkan pada thallus rumput laut ditemukan penempelan $C$. crassa. pada minggu ke-2 diikuti dengan kemunculan spesies makroepifit seperti polysiphonia sp., E. flaccida dan A. clathroides. Pada minggu ke-3 tidak ditemukan penempelan spesies baru baik pada thallus rumput laut maupun substrat. Minggu ke-4, ditemukan penempelan spesies makrofauna pada tali yaitu jenis $M$. sallei. Minggu ke-5, penempelan spesies $P$. australis pada tali tidak ditemukan lagi. Memasuki minggu ke-6, penempelan spesies $C$. crassa mulai menghilang dari substrat maupun thallus rumput laut, dan digantikan kehadirannya dengan spesies $U$. fasciata 


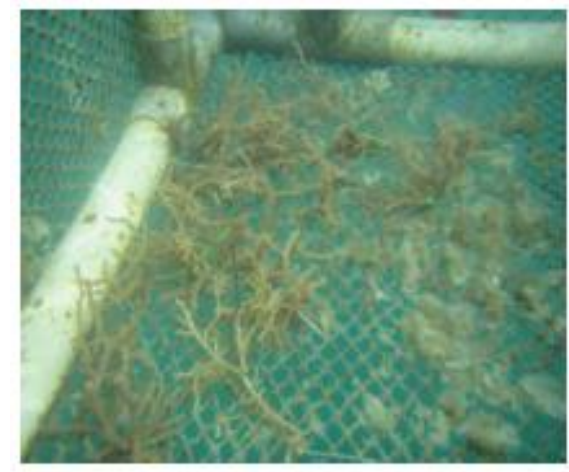

(a)

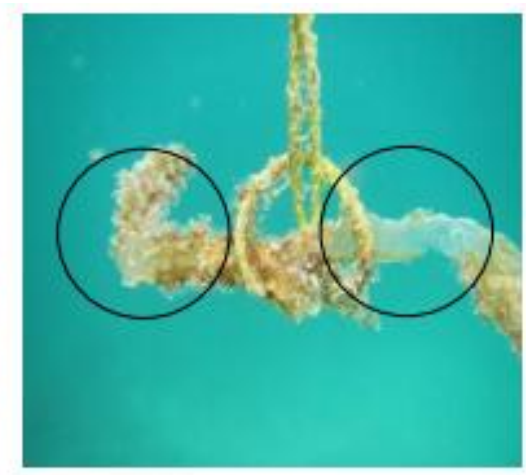

(b)

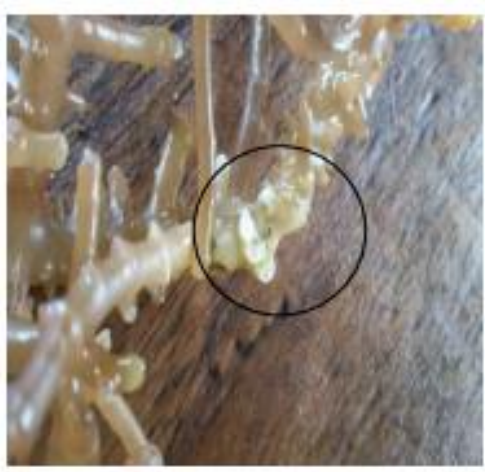

(c)

Gambar 3. (a) Proses budidaya rumput laut dengan menggunakan rakit jaring apung; (b) Thallus rumput laut yang rusak akibat pemangsaan organisme herbivore; (c) Thallus rumput laut yang lembek akibat penempelan biofouling

Hasil pengukuran kualitas air yaitu suhu berkisar 30-34 $4^{\circ}$, salinitas berkisar $31-35 \%$, kecepatan arus berkisar 13,42-23,79 m/s, kecerahan berkisar 4,65$6,85 \mathrm{~m}$, nitrat berkisar $0,0107-0,0165 \mathrm{mg} / \mathrm{L}$ dan fosfat berkisar antara 0,0011-0,0091 mg/L (Tabel 3).

\section{Pembahasan}

Penempelan biofouling pada thallus rumput laut yang dipelihara pada rakit jaring apung ditemukan sebanyak 4 spesies, sedangkan pada long line sebanyak 3 spesies. Hasil penelitian Rejeki (2009) di Perairan Bulang, Batam ditemukan penempelan biofouling pada tanaman rumput laut sebanyak 5 spesies. Murniati, et al (2015) melakukan penelitian tentang penempelan biofouling pada jaring dan ditemukan sebanyak 7 spesies.

Puncak penempelan biofouling mulai terjadi pada minggu ke-4 penelitian. Hal tersebut diduga akibat peningkatan konsentrasi unsur hara di perairan (Tabel 3). Peningkatan konsentrasi unsur hara di perairan dapat memacu pertumbuhan biofouling. Effendi (2003) melaporkan bahwa ketika kadar nitrat dan fosfat melimpah di perairan maka akan memacu reproduksi dari makroalga.

Tingginya kepadatan biofouling pada rakit jaring apung disebabkan oleh pergerakan arus didalam rakit karena terhalang oleh jaring sehingga menyebabkan spora biofouling lebih banyak menempel pada jaring. Braithwaite \& McEvoy (2005); Willemsen (2006); De sa et al (2007) menyebutkan bahwa penempelan biofouling pada jaring akan menyebabkan sirkulasi air menjadi terhambat sehingga spora biofouling dalam badan air dapat dengan mudah menempel sehingga menyebabkan rakit menjadi lebih berat. Safriel et al
(1993); Davis et al (1989) melaporkan bahwa melaporkan bahwa kepadatan biofouling tertinggi pada jaring adalah spesies Enteromorpha clatharata. Hasil penelitian serupa dilaporkan Murniati $d k k$ (2015) yang menyebutkan bahwa kepadatan biofouling tertinggi pada tanaman rumput laut adalah jenis Enteromorpha sp. Tingginya kepadatan jenis $P$. australis dan $C$. crassa di lokasi penelitian dikarenakan jenis ini merupakan jenis makroalga dengan tingkat pertumbuhan yang sangat cepat dibandingkan dengan jenis yang lain. Atmadja (1992) menyebutkan bahwa beberapa jenis makroalga seperti A. spicifera, Padina dan Hypnea memiliki daya penyebaran spora yang luas, daya tahan hidup serta daya lekat yang tinggi.

Banyaknya spesies biofouling yang ditemukan pada rakit jaring apung dikarenakan adanya jaring dan pipa yang dapat ditempeli biofouling. Adanya jaring dan pipa membuat organisme fouling dapat menempel dan membentuk kolonisasi. Abarzua and Jakubowski (1995) melaporkan bahwa permukaan substrat berupa jaring sangat cocok terhadap penempelan bakteri yang menjadi dasar terjadinya koloni biofouling. Walaupun rakit jaring apung sangat rentan terhadap penempelan biofouling, tetapi pertumbuhan dan produksi bersihnya lebih tinggi dibandingkan long line (Gambar 1 dan 2). Kasim et al (2016) melaporkan bahwa hasil produksi rata-rata $E$. denticulatum yang dibudidayakan dengan rakit jaring apung mencapai 74-78 kg setiap kurungan, sedangkan produksi ratarata long line mencapai $63-70 \mathrm{~kg}$ setiap unit (selama periode penanaman 50 hari). Tingginya pertumbuhan dan produksi bersih rumput laut yang dipelihara menggunakan rakit jaring apung dikarenakan 
40 Isman Septian Ismail et al.

JURNAL SAINS dan INOVASI PERIKANAN / Journal of Fishery Science and Innovation

Vol. 1, No. 2, 35-41, Juli 2017

konstruksi alat yang melindungi rumput laut dari pemangsaan organisme herbivora. Hurtado-Ponce (1992) menyebutkan bahwa peneliti menyarankan agar budidaya rumput laut dilakukan didalam kurungan sehingga dapat mencegah rumput laut dari serangan organisme herbivora (Gambar 3a). Rendahnya pertumbuhan dan produksi bersih long line diakibatkan oleh proses pemangsaan organisme herbivora. Dari hasil pengamatan di lapangan ditemukan adanya thallus rumput laut yang rusak akibat pemangsaan (Gambar 3b). Perez-Enriquez (1996) melaporkan bahwa tingkat pertumbuhan rumput laut menunjukkan penurunan yang signifikan dikarenakan kehadiran organisme herbivora dan penyakit ice-ice.

Hasil yang sama dilaporkan oleh Ganesan et al (2008) melaporkan bahwa fenomena pemangsaan ikan herbivora dapat menurunkan produksi rumput laut hingga 10\%. Kasim and Mustafa (2017) menyebutkan bahwa kehadiran ikan herbivora (Siganus sp.) lebih banyak pada long line daripada rakit jaring apung. Hal tersebut dikarenakan konstruksi long line yang terbuka sehingga memudahkan organisme herbivora melakukan pemangsaan thallus.

\section{KESIMPULAN}

Penempelan biofouling ditemukan lebih banyak pada rakit jaring apung daripada long line. Akan tetapi, pertumbuhan rumput laut yang dipelihara pada rakit jaring apung lebih tinggi dibandingkan dengan long line. Rakit jaring apung dapat meminimalisir pemangsaan thallus oleh organisme herbivora.

\section{DAFTAR PUSTAKAN}

Abarzua, S., Jakubowski, S. 1995. Biotechnological investigation for the prevention of biofouling. Biological and biochemical principles for the prevention of biofouling. Marine Ecology Program. 123: 301-312.

Ahmed, N., Taparhudee, W. 2005. Seaweed Cultivation in Bangladesh : Problems and Potentials. Kasetsart University Fisheries Research Bulletin. 28: 13-21.

Ask E. I., Azanza, R. V., 2002. Advances in cultivation technology of commercial eucheumatoid species: a review with suggestions for future research. Aquaculture. 206: 257-277.
Athithan, S. 2014. Growth performance of a seaweed, Kappaphycus alvarezii under lined earthen pond condition in Tharuvaikulam of Thoothukudi coast, South East of India. Research Journal of animal, Veterinary and Fishery Science. 2(1): 610.

Atmadja, W. S. 1992. Rumput Laut Sebagai Obat. OSEANA. 17(1):1-8.

Barret, J., Yonge, C.M. 1985. Collins Pocket Guide to The Sea Shore. South China Printing Co. Hongkong. 157 pp.

Braithwaite, R.A., McEvoy, L. 2005. Marine Biofouling on Fish Farms and Its Remediation. Adv. In Marine Biology. 47: 215-252.

Dawes, C. J. 1981. Marine Botany. New York: John Wiley and Sons, University of South Florida. 268 pp.

De Sá, F., Nalesso, R., Paresque, K., 2007. Fouling organisms on Perna perna mussels: is it worth removing them? Brazilian J. Oceanogr. 55(2): 155-161.

Davis, A. R., Targett, N. M., McConnel, O. J., Young, C. M. 1989. Epibiosis of marine algae and benthic invertebrates: natural products chemistry and other mechanisms inhibiting settlement and overgrowth. Bioorg Mar Chem. 3: 85-114.

Effendie, H. 2003. Telaah Kualitas Air Bagi Pengelolaan Sumber Daya dan Lingkungan Perairan. Kanisius. Yogyakarta. 258 hal.

Evans, L.V., Hoaglands, K.D. 1986. Algae Biofouling : Studies in Environmental Science 28. Elsevier Science Publishing Company Inc. New York. 318 pp.

Ganesan, P., Chandini, S.K., Bhaskar, N. 2008. Antioxidant properties of methanol extract and its solvent fractions obtained from selected Indian Red Seaweeds. Bioresour. Technol. 99: 27172723.

Hodson, S.L., Burke, C.M., Bisset, A.P. 2000. Biofouling of Fish-Cage Netting: The Efficacy of a Silicone Coating and The Effect of Netting Colour. Aquaculture 184: 1277-290.

Hurtado-Ponce A. Q., 1992 Cage culture of Kappaphycus alvarezii var. tambalang (Gigartinales, Rhodophyceae). Journal of Applied Phycology 4:311-313.

Kasim, M., Asnani, 2012. Penetuan musim reproduksi generative dan preferensi perekatan spora rumput laut Eucheuma cottoni. Ilmu Kelautan.17(4): 209216. 
Kasim, M. 2016. Makroalga, Kajian Biologi, Ekologi, Pemanfaatan dan Budidaya. Penebar Swadaya. Jakarta.

Kasim, M., Mustafa, A., Munier, T. 2016. The growth rate of seaweed (Eucheuma denticulatum) cultivated in longline and floating cage. AACL Bioflux. 9(2): 291-299.

Kasim, M., Mustafa, A. 2017. Comparison growth of Kappaphycus alvarezii (Rhodophyta, Solieriaceae) cultivation in floating cage and longline in Indonesia. Aquaculture Reports. 6 : 49-55.

Kavale, M. G., Sreenadhan, N., Singh, V. V. 2016. Cultivation of Kappaphycus alvarezii (Doty) ex P.C. Silva along the coast of Palshet, Guhagar, Maharashtra. Indian Journal of Geography and Marine Science. 45(5): 666-670.

Lacoste, E., Le Moullac, G., Levy, P., Gueguen, Y., Gaertner-Mazouni, N. 2014. Biofouling development and its effect on growth and reproduction of the pearl oyster Pinctada margaritifera, in suspended cultures of French Polynesia. Aquaculture. 434: 18-26.

Murniati, E., Notowinarto., Ramses. 2015. Distribusi dan keragaman populasi Biofouling pada tanaman rumput laut Budidaya di perairan Bolang Batam. Simbiosa. 4(1): 21-26.

Ohno, M. 2004. Development of the seaweed cultivation and industry in Japan. Abstracts, $7^{\text {th }}$. Asian Fisheries Forum 2004, 226 pp.

Patadjai, R. S. 2007. Pertumbuhan, Produksi dan Kualitas rumput laut Eucheuma Denticulatum (Doty) Doty pada berbagai habitat budidaya yang berbeda. Disertasi. Program Pasca Sarjana Universitas Hasanuddin Makassar. 163 hal.

Perez-Enriquez. R. 1996 Growth of Eucheuma isiforme (C. Agardh) J. Agardh on experimental raft off the coast of Yucatan State, Mexico. Journal of Applied Phycology 8: 27-28.

Railkin, A. I. 2004. Marine Biofouling; Colonization Processes and Defence. CRC Press. Florida.

Rejeki, S. 2009. Suksesi Penempelan Makro MarineBiofouling Pada Jaring Keramba Apung di Teluk Hurun Lampung. Ilmu Kelautan. 14(2): 112-117.

Sievers, C. K., Shanle, E. K., Bradfield, C. A., Xu, W. 2013. Differential action of monohydroxylated polycyclic aromatic hydrocarbons with estrogen receptors $\alpha$ and $\beta$. Toxicol Sci. 132: 359-367.

Soegiarto, A., Sulistijo. W, S., Atmaja., Mubarak, H. 1978. Rumput Laut (Algae), Manfaat, Potensi, dan Usaha Budidayanya. Lembaga Oseanografi Nasional-LIPI. Jakarta. 49 pp.

Tan, C.K.F., Nowak, B.F., Hodson, S.L. 2002. Biofouling as Reservoir of Neoparamoeba pemaquidensis, The Causive Agent of Amoebic Gill Disease in Atlantic Salmon. Aquaculture. 210: 49-58.

Trono, G. C. 1986. Guide To Philippine Flora and Fauna. Natural Resources Management Center, Ministry of Natural Resources and University of The Philippines. Philippine. 84 pp.

Thirumaran, G., Anatharaman, P. 2009. Daily Growth Rate of field Farming Seaweed Kappaphycus alvarezii (Doty) ex. P. Silva in Vellar Estuary. World Journal of Fish and Marine Sciences. 1(3): 144-153. 